Original Research Paper

\title{
Cognitive Mechanism of Metaphorization in Zoological Terms
}

\author{
${ }^{1}$ Zifa Kakbaevna Temirgazina, ${ }^{2}$ Uldanai Maksutovna Bakhtikireeva, \\ ${ }^{2}$ Vladimir Pavlovich Sinyachkin and ${ }^{3}$ Marzhan Kasymovna Akosheva \\ ${ }^{1}$ Pavlodar Pedagogical Institute, Pavlodar, Kazakhstan \\ ${ }^{2}$ Peoples' Friendship University of Russia, Moscow, Russian Federation \\ ${ }^{3}$ S. Toraigyrov Pavlodar State University, Pavlodar, Kazakhstan
}

\author{
Article history \\ Received: 26-08-2016 \\ Revised: 11-12-2016 \\ Accepted: 13-12-2016 \\ Corresponding Author: \\ Zifa Kakbaevna Temirgazina \\ Pavlodar Pedagogical Institute, \\ Pavlodar, Kazakhstan \\ Email: zifakakbaevna@mail.ru
}

\begin{abstract}
Terminology of any science, as a result of verbalized scientific expertise, is formed in conjunction with the ordinary consciousness of native speakers. Metaphor in a particular scientific zoological discourse in the Russian and Kazakh languages has not become the object of researchers' attention yet. The comparison of the results of the cognitive mechanism of analogy in the zoological discourse in languages genetically and structurally not identical to each other is of research interest. Comparative analysis of scientific zoological terminology in the Russian and the Kazakh languages confirms the metaphorical nature of the scientific language, generated by the cognitive mechanism of analogy. Most of terminology metaphors in zoo-discourse are modeled on the universal archetype-anthropomorphic, zoomorphic and dendromorphic. Metaphors generated within universals are identical in the Russian and the Kazakh languages. Greco-Latin designations of zoological concepts to which metaphors date back also rely on identified metaphorical universals. In scientific communication the metaphorical expression functions as a readymade term, transmitting scientific information in accordance with the target settings of communication participants. Comparative analysis of metaphoric terms in the Kazakh and the Russian zoological discourse reveals that some terms are different due to different structural features of languages and the differences in the choice of signs that take place in the mechanism of analogy, which is caused by the peculiarities of understanding of the world, geographical, climatic, economic and living conditions of the Russians and the Kazakhs. The scientific metaphor is formed on the basis of conceptual structures already formed in each of the ethnic cultures. There are no rigid boundaries between scientific thinking and the "profane" consciousness; scientific knowledge uses common human knowledge of the world in the process of presenting knowledge in a particular field of science.
\end{abstract}

Keywords: Cognitive Mechanism of Metaphorization, Zoological Terms, Particular Scientific Discourse, Metaphorical Model, Metaphorical SubModel, Metaphorical Universals, Anthropomorphic Model, Zoomorphic Model, Dendromorphic Model

\section{Introduction}

The development of the terminology of any science usually runs in two main stages. In the first stage, which can be called a preparatory, basic one, the formation of the complex of special terms as a result of scientific and human cognitive activity in a certain area takes place. At this stage, each terminological nomination passes the selection stage and the compliance test. In the second stage, after the withstand test it becomes part of an established terminological science sector. Longitude of its life in a terminological system is determined by discourse and time.

If the theory in which the term originated is verified in the course of further development of scientific knowledge and the selection of the term form is successful, it is secured in the terminological system of the scientific branch as its permanent member with all its attendant systemic-structural relationships. "Otherwise, at a new stage of development of scientific knowledge, 
this special category falls out of the terminological system and actually should no longer qualify for the term" (Sedov, 2000).

In contemporary cognitive science, terminological system is seen as a crucial component of the particular scientific picture of the world, for example, the physical picture of the world, the chemical picture of the world, etc. Kornilov (1999) writes that the main method of recording the scientific picture of the world is particularly "terminologies of certain sciences, exploring the world or some of its components from different points of view". According to two main stages of term formation, a number of researchers divide a set of terminology nominations into terminology proper and terminological system. These are opposed by parameters of the systematicity-asystematicity, conformity to planspontaneity, as well as uniqueness-ambiguity. For our work the idea is important that the terms of any science, as a result of verbalized scientific expertise, are formed in a close and direct relationship with the ordinary, "profane" consciousness of native speakers. In other words, the process of scientific cognition of reality is largely based on the existing human knowledge acquired in the course of pre-scientific understanding of the world and constants of everyday consciousness are used in the scientific categorization. Croft and Cruse (2004) believe that metaphors are everyday colloquial forms of conceptualization, which are closely linked with the human experience, with the surrounding world and the individual's bodily and mental sensations. Thus, the works by (Shimizu et al., 2006a; 2006b) based on the experimental data of cognitive processing of adjectives with emotional meaning can be noted among the recent research of cognitive mechanisms of ordinary consciousness and their impact on the emotional and psychological perception of man

One may talk that the scientific pictures of the world are closely linked and actively cooperate with the "naïve" view of the world, moreover, without this interaction particular scientific pictures of the world look flawed and incomplete. Mishankina (2010) writes: “... The scientific picture of the world is formed as part of a national worldview and may not reflect the specificity of attitude inherent in a particular national mentality, although it gears towards leveling ethnic differences" (Mishankina, 2010). When a person is faced with the necessity of reflection and interpretation of new scientific data, with the problem of integration of new scientific information in the existing conceptual model of the world, available scientific picture, he/she relies on cognitive mechanisms based on the principle of similarity, analogy, i.e., in the metaphorical mechanisms. As studies currently available in the field of scientific metaphor show, this cognitive mechanism is very effective and widespread in the scientific discourse in various fields.
Demand for cognitive mechanism of metaphorization in scientific discourse is defined by specificity of scientific knowledge itself: Firstly, by the interaction of two different ways of knowledge-rational and irrational (intuitive); secondly, by combinability of new/unknown and familiar information that serves as a support for the new knowledge; thirdly, by handling holistic cognitive structures, such as frames, scripts, Gestalt and so on.

Cognitive interpretation of metaphorization process was first introduced in the works of American scientists (Lakoff, 1990; 1998; Johnson, 1987). It was later supplemented by a theory of conceptual integration by (Fauconnier and Turner, 1998). The key idea to cognitive theory of metaphor is the idea that "the basis of metaphorization is procedures of knowledge structures processing-frames and scenarios" and knowledge, which is realized in them, is "a compilation of the experience of human interaction with our environment-both with the world of objects and the society" (Lakoff, 2004). This idea contributed to substantial transformation and revision of the traditional theory of metaphor as it represented a metaphor primarily as a psychic and not a language phenomenon. In other words, verbal metaphors arise as a result of cognitive mechanism of analogy in the human mind. Metaphorical model is a basic cognitive model, built on the human's ongoing analogy knowledge of one object with information about another object. Carrying the analogy is determined by various factors, such as artistic and aesthetic challenges in the case of the author's understanding of already known information about the phenomenon, event; cognitive tasks and the need for theoretical understanding of the new object, unknown data in the scientific discourse. "The scientific metaphor is viewed as an integral component of scientific work, every metaphor, including expressive one, is in a certain sense, the hypothesis of the new properties of the object. It is the hypothetical character that is involved in heuristicity of metaphor" (Makhnitskaya, 2003).

The interpretation proposed by (Lakoff, 1990; 1998; Johnson, 1987) enables us to consider a metaphor in the language not as an isolated fact, but as one of the elements of the system of verbal representations of concepts and metaphorical analogue model that exists in the minds of native speakers. This system of verbal representations in scientific discourse, as we assume, possesses a steady, regular nature based on the strength and stability of the conceptual structure in the mental world of a human being. Hence is the universal character of sets of metaphorical terminological units in scientific discourses differing in structure and genesis of language, as will be shown later in this article. Metaphors peculiar only to specific languages are generated by specific conceptual structures as a whole, or specific elements in them with an overall similarity. 
In the Russian linguistics the problem of metaphor in scientific discourse has been studied profoundly. The object of study was presented by terminological metaphors in general scientific discourse (Baranov, 2004; Gusev, 1984; Stepanov, 1995; 1998; Kuliev, 1987), in some particular academic discourses: Mathematical and physical (Serbinovskaya, 2009) computer (Galkina, 2004), linguistic (Ovsyannikov, 2009; Rezanova, 2007a), genetic (Rezanova, 2007b), health (Dudetskaya, 2007), of natural science (Mishankina, 2010), economic (Makhnitskaya, 2003) and others. Metaphor in particular scientific zoological discourse of the Russian and the Kazakh languages has not become the object of attention of researchers yet, which determines the novelty of this work. An attempt undertaken in this article to compare the results of the cognitive mechanism of analogy in the zoological discourse of two languages which are genetically and structurally non-identical-Russian and Kazakh-is of special research interest.

The purpose of this article is to study and compare metaphorical models in the Russian and Kazakh zoological scientific discourse, which, in addition to the theoretical significance, aims at practical objectives as well: Improving the practice of creating new zoological terms on the basis of the already studied metaphorical models, adding new information in their lexicographical description in terminological dictionaries with scientific and educational purpose, including zoological bilingual dictionaries-Russian-Kazakh, Kazakh-Russian. The findings of the study "can be used to create the learner's dictionaries in English on physics, chemistry, etc. for schools with the Kazakh language of instruction. The proposed principles for the development of learner's terminology dictionaries can be extended and popularized in a scientific and methodical community in Kazakhstan, the CIS countries and the world scientific community" (Temirgazina et al., 2016).

\section{Methodology}

The methodology of research is based on the theory of conceptual metaphor of (Lakoff, 1990; 1998; Johnson, 1987), providing for the technique of describing cognitive mechanism of analogy in both languages The concept of "metaphorical model" is defined as a generalized verbalized representation of a formula consisting of two elements: Nomination of the source sphere of knowledge and nomination of the target sphere involved in the process of zoological term metaphorization.

Taking into consideration the framing-scenarioscriptum nature of mental foundations of metaphorization, we take into account the principle, or the Invariance Hypothesis, formulated by Lakoff (1990). This hypothesis suggests that with the metaphoric projection in the target sphere the structure of the source sphere is partially preserved. Consequently, the concept of "metaphorical sub-model" can be introduced in the method of describing metaphorical zoological terms, which will allow detailing the source sphere by its constituent elements.

The Thesis studies of the process of metaphorization of scientific terminology in English and Russian by (Galkina, 2004; Dudetskaya, 2007) describe the basic conceptual source fields of terms in many sciences: Human, fauna, flora, war, nature (landscape, climate), artifacts (clothing, fabric, tools, food, architecture, etc.). This article will consider the metaphorical models of zoological terms with the source sphere of "person", "fauna".

\section{Results}

The universal base for term creation almost in all sciences is an anthropomorphic model which is contrasted to zoomorphic model by the researcher Z.I. Rezanova who considered it as a product of the functional paradigm of sciences (Rezanova, 2007a) and, really, who and what do people know better than themselves, their bodies? And they projects this reliable information to the knowledge of objects less known to them. Stepanov (1998) wrote about it: "Through metaphor the speaker (and therefore every person) sequentially isolates other worlds from the world defined by coordinates "I-here-now" from the close range, adjacent to his/her body and coinciding with the moment of his/her speech". This argument emphasizes the bodily and subject-objective nature of scientific metaphors. Such metaphorical models belong to the earliest scientific metaphors, since they are based on very ancient cognitive mechanisms that are rooted in mythological thinking. Scientific thinking originally dates back to the mythological consciousness, based on the myth as does a multi-storeyed building on the foundation. These models are widely distributed in almost all branches of science, are regularly reproduced and repeated. These characteristics make it possible to regard them as metaphorical archetypes of scientific discourse.

In the zoological terminology, the most frequent model of anthropomorphic metaphor, in which the source of the scientific understanding and categorization of special concepts is a human being in his/her various guises, is the model with the source "parts/organs of a person".

\section{Metaphorical Model [Structure/Part of the Human Body] $\rightarrow$ [Animals]}

The information on the structure and organs of the human body is used:

- The general appearance, for example, in the Russian language: Krasnoye telo [a red body] (glandular 
epithelium on the surface of the swim bladder of fish), krovyanye teltsa (blood cells). In the Kazakh language, these terms are constructed in similar metaphorical patterns: Қызыл түйіршік (glandular epithelium), қан түйіршіктері (blood cells)

- The function of parts of the body: In the Russian language: Ruki [hands] (located around the mouth of the cephalopods 8 or 10 long rope-formed prehensile organs bearing the suction cups), limfaticheskiye serdtsa [lymphatic "hearts"] (pulsing parts of lymphatic vessels, due to the reduction of which the lymph in fish, amphibians and reptiles moves); in the Kazakh language: Қолдары [hands], лимфалық «жүрек» [lymphatic "heart"]

- The form: In Russian: Kisteperye [crossopterygians] (one of the subclasses of fish characterized by a peculiar structure of the fin skeleton that resembles the skeleton of five-toed limbs), rukopyorye [Pediculati] (one of the groups of bony fish), rukokrylye [bats] (one of the mammalian groups, whose wings are leathery membranes located between the fingers of the front limbs, body sides, hind limbs and tail), resnichki [cilia] (short protoplasmic cell outgrowths committing rowing movements, are organelles of motion), resnitsy mertsatelnogo epiteliya [cilia of ciliated epithelium]; in the Kazakh language: Қолққанаттылар [crossopterygians] кірпікшелер (cilia), жыпылықтайтын эпителий кірпікшелері (cilia of ciliated epithelium). Russian term kisteperye [crossopterygians] corresponds to the Kazakh term саусаққанаттылар that is literally translated as "paltseperye" [fingeropterygians]. As we can see, for natives of the Kazakh language a fingerdesignation of a part-is a metonymic substitute for the name of the whole. Metonymy as a cognitive mechanism in this case accompanies metaphorization process in term creation

As lexical objectification of the designated lexical conceptual field are various somatic nominations in the Russian and the Kazakh languages.

The metaphoric terms of Greek and Latin origin, operating in the Russian and Kazakh scientific discourse, confirm the universal character of the model under consideration: Trikhotsysty [trichocysts] (cytoplasmic organelles of protozoa emitted with mechanical or chemical irritation) from Greek thrix [hair]; nefrostom [nephrostome] (ciliary metanephridia funnel opening into the body cavity) from Greek nephros [kidney], stoma [mouth, opening]; aurikuliariya [auricularia] (free-swimming larvae of sea cucumbers), from Lat. auricula [ear pinna]; pinotsytoz [pinocytosis] (capture with cell surface and absorption of the liquid by cell) from Greek pino [drink] and others.
Metaphorical Model [Family, Genus] $\rightarrow$ [Animals]

Metaphorical Sub-Model [Person's Associations] $\rightarrow$ [Species]

The conceptual source field "family, genus", which is widely used in the processes of metaphorization of zoological knowledge, is applied to the anthropomorphic model.

This is due, probably, to the fact that the family/genus is the earliest and the main way of social organization of human civilization. Family and kinship relations are presented to anyone as a familiar and close sphere of knowledge, that is why the concept of "family/genus" as a kind of bringing people together in society is often utilized by the cognitive mechanism of metaphorization when it is necessary to nominate any collection of things, objects (living and non-living) on the basis of a common feature or causal relationship with a source object in the scientific taxonomy.

The versatility of metaphorical sub-model under consideration should be dealt with. Many of the terms of Greco-Latin origin, which is the basis of biological terms, are formed due to this metaphorical mechanism. For example: Filogenez [phylogeny] from Greek phylon [clan, tribe]. See also, for example, similar zoological taxonomy terms in the Russian language: semeistvo [the family]-a systematic category combining related genera and included in the order: Semeistvo plotnorogikh [the family Cervidae], ili oleney [or deer]; semeistvo koshach'ikh [cat family]; a genus-a systematic category uniting closely related species and which is part of a family: Rod dvukrylykh nasekomykh [genus of Diptera], rod bryukhonogih mollyuskov [genus of gastropods]. In Kazakh mұkblмdac (family) is a taxonomic category in biological classification, which is close in meaning to the word "family". It has a meaning of "one breed/sort/seed" for the animals, "one genus/tribe" for people, unites animals of the related genera. The word is included in the order: Ульл жыландар тұқымдасы (family of poisonous snakes), итбалықтар тұқымдасы (family seals); mуыс (affined): ит тұқымдасының түлкі myысы (kind of fox canines), кемірушілер тұқымдасының тышқандыр туысы (genus Muridae of the family of rodents). The semantics of the lexical units mұқымдас, family, rising in both languages to the concept of "seed", has been saved in people's ordinary ideas about the methods and principles of the organization of their society, as reflected in the naive systematization of the surrounding wildlife.

Methods, principles, forms of human social organization increasingly complex over time are an inexhaustible source of metaphorical comparisons in the scientific biological discourse. Losev (1977) noted a similar trend at the members of the tribal community, whose "ancestral relationship of animate beings is 
directly transferred to the surrounding world, so that the whole world is like a huge tribal community".

\section{Metaphorical Sub-Model [Subjects of Family and Kinship] $\rightarrow$ [Animals]}

Family and kinship, their specificity, the actors involved in them, especially some particularities are used for metaphorization of not only taxonomic concepts, but specific zoological processes and objects in scientific discourse. For example, the Russian terms of Greek origin: Gameta [gamete] (sexual reproductive cell of animals) from Greek gamete [wife], gametes [husband]; partenogenez [parthenogenesis] (virgin reproduction, in which the female sex cells develop without fertilization), from Greek parthenos [virgin]; pedoenez [paedogenesis] (method of reproduction inherent in a number of invertebrates) from Greek pais, genitive case paidos [child] and in the Russian language: Tainobracnye [cryptogams] (spore) organisms; in the Kazakh language: Құпия некелі (sporalylar) авзалар; неке here denotes the Muslim rite of marriage.

\section{Metaphorical Model [Social Relations] $\rightarrow$ [Animals]}

A variety of relationships in the social sphere of human life become a source of naming relationships between objects of zoosphere, creating a set of terms. In this model it is possible to single out a number of metaphorical sub-models.

\section{Metaphorical Sub-Model [Economic Relations of Ownership] $\rightarrow$ [Zoological Concept]}

This sub-model has created such zoological terms, as the following: In the Russian language khozyain [host] (the body in which other organism is a parasite), smena khozyaev [change of owners] (dwelling of a parasite at different stages of development in organisms of different animals; an animal in which a mature stage lives is called the primary master and an animal in which the larval stage lives is called intermediate); kvartirantstvo [renting] (settlement of the same species in buildings serving housing for different species or individuals of one species in individuals of other species without causing harm to the latter); there are similar examples in the Kazakh language: иe (host), иесінің ауысуы (change of owners), nәтертұрушылық (renting).

The similarity of examples supports the idea that the conceptual picture of the world is the same in all people by virtue of the unity of the human mind, the availability of the system of the most general ideas about the world. These metaphors are examples of ways to create a cognitive linguistic world.

\section{Metaphorical Sub-Model [Way of Living/Lifestyle] $\rightarrow$ [Animal]}

Zoological terms built according to this sub-model, characterize:
The way of animal life in the Russian language: Kosmopolity [cosmopolitan] (forms of organisms which are very widespread on Earth occurring wherever there are suitable conditions for their existence); rak-otshelnik [hermit crab], kolonialnye organozmy [colonial organisms] (organisms in which at reproduction asexually, child generations remain connected to the mother's body), zimniy klub "Winter Club" (a close bunch of bees in the hive in winter). Last metaphor retains its imagery, "freshness", so it is often enclosed in quotation marks in terminological dictionaries, underlining its unconventional character. In the Kazakh language: Космополит жануарлар (cosmopolitan animals); колониялық авзалар (colonial organisms), такуа шаян (hermit crab, literally, "a devout cancer"). In the last example, we see the difference in the mechanism of metaphorization in the Kazakh and the Russian term. If in the Russian language, the source sphere to characterize a cancer is an image of human life in general (asceticism), then in the Kazakh language-religious concepts come to the fore: Takya "devout; righteous";

The movement of organisms in the Russian language: Immigration (method of forming a two-layer embryo through the introduction of a group of cells in the inner cavity of a single layer embryo), immigrants (animals have migrated to this area from other areas). The Kazakh zoological discourse does not use international metaphorical terms immigration, immigrants. Instead of them nominations көші-коон (method of forming a twolayer embryo through the introduction of a group of cells in the inner cavity of a single layer embryo) function as metaphors, көші-қон жануарлар (animals having migrated to this area from other areas), which reflect the national specific conceptualization of these concepts. Көші-қон includes not just to "move", but to "settle down/get" in its semantics, thus combining idioethnic syncretic concept that is key to the Kazakh nomadic culture. This fundamentality of the concept, characterizing the basic way of life of the nomadic people, does not allow the use of other, alien designations and prevent from keeping them secured in the Kazakh language discourse.

\section{Metaphorical Sub-Model [Occupation] $\rightarrow$ [Animal]}

The basis for the use of knowledge from the sphere of "Occupation" can be both a location, see the Russian language: Privratnik [pylorus, literally "gatekeeper"] (narrowing of the stomach, which passes into the duodenum) and the exterior, for example: Senokostsy [Opilliones] (one of orders of class of arachnids, differing from spiders by the broad fusion of the two body segments and very long thin legs). In the Kazakh language, unlike Russian, the name дарбазашы (pylorus, literally "gatekeeper") is not used, instead the 
term асқазан құалmқысысы (literally "stomach float") is used, also indicating the location of the narrowed part of the stomach. Kazakh term шөп шабушы is similar to the Russian term senokosets [Opilliones].

\section{Metaphorical Model [Animals] $\rightarrow$ [Other Animals]}

The fauna as a source sphere of metaphorical conceptualization is involved in epistemological modeling in certain scientific fields (such as volchya past [cleft palate], stadiya gadkogo utenka [an ugly duckling stage]), but they are not universal for the discourse as a whole, as opposed to the sphere of "person". Zoomorphic model of knowledge, as well as anthropomorphic one, could be attributed to the archetypes of scientific knowledge because of its mythological and "folkloric" nature, although it is different from it by its lesser prevalence in various scientific discourses. In connection with the subject of the present research it is important to note that knowledge of some living organisms is used as a source of knowledge of other organisms with the help of metaphorization mechanism.

Arguing within the discursive interaction and intersection, we can say that metaphorical model under analysis is related to the sphere of intradiscursive interaction.

See terms of Greco-Latin origin, created on this model: Coracidium (free-swimming larva of some tapeworms, covered with a layer of ciliated cells) from Greek kotax, genitive case of korakos [crow] and also something bent like a hook, like a crow's beak; chelicerae (the first pair of limbs at the head of chelicerae, which are used as jaws for grasping and tearing prey) from Greek chele [claw], keras [horn]; bipinnaria (free-swimming larvae of sea stars), from Lat. bi [double], pinna [feather]; pedipalps (the second pair of jointed limbs of cephalothorax) from Latin. pedis [the foot], palpus [tentacles] and others.

As an example, we can mention the other Russianlanguage terms: Morskiye petukhi [gurnard] (a family of fish, order Perciformes), morskiye sobachki [blennies] (a family of fish, order Perciformes, during low tides move over land by jumps using fins), myagkoperye [anacanthine] (one of the suborders of clawed fish), morskiye svinyi [porpoises] (a genus of dolphin up to 2 $\mathrm{m}$ ), morskiye slony [elephant seals] (genus of mammals family of seals up to $6,5 \mathrm{~m}$ and weighing up to 3.5 tons; there is a bulge like a short trunk on the head in males), morskiye lvy [sea lions] (pinnipeds family of eared seals with length up to $3.6 \mathrm{~m}$ and weighing up to $400 \mathrm{~kg}$ ), morskiye lisitsy [thrasher] (a family of fish, superorder sharks up to $6 \mathrm{~m}$ long, the huge tail fin is about half of the body), morskiye zaitsy [squareflippers] (genus of mollusk, subclass opisthobranchia up to $40 \mathrm{~cm}$, the rear pair of tentacles resembles rabbit ears in the form), morskiye yezhi [sea urchins] (invertebrates class such as echinoderms), molochko pchel [brood food] (protein substance produced in one of the specific pairs of salivary glands of worker bees, with which they feed the larvae). In the Kazakh language: теніiз иттерi (blennies), қауырсыны жұмсақ қанаттылар (anacanthine), теңіз шошқалары (porpoises), тенуіз пілі (elephant seal), теңіз арыстаны (sea lion), теңңіз түлкісі (thrasher), теңіз құяны (squareflippers), теңзіз кipnici (sea urchin), apa cymi (brood food).

Conventionally related to this model are metaphors generated by religious and mythological discourse, or rather, the concept denoting mythical creatures. See, for example, in the Russian language, morskiye cherty [monkfish] (a family of fish, order anglerfish up to $1.5 \mathrm{~m}$ and weighing up to $20 \mathrm{~kg}$ ), morskiye angely [angelfish] (genus of pteropods with the length up to $5 \mathrm{~cm}$ ); in the Kazakh language, теңіз шайтаны [monkfish], теңіз nepiumeci [angelfish]. These terminological combinations are built in Russian and Kazakh languages according to the same type of structural and semantic model [adjective morskoy referring to sea/ mең̧iз] + [name of animal]. The first component of the structural and semantic model describes the habitat of the organism and the second-an animal or a mythological creature from the source sphere.

Note that the concepts from the source spheres of "birds', "horned animals", "mammals" are transferred to categorize concepts in the areas of "marine organisms", "fish", "insects", i.e., we can state the following trend in zoomorphic metaphor when knowledge of higher organisms allow metaphorically conceptualizing and nominating the concepts of lower organisms.

\section{Metaphorical Model [Plants] $\rightarrow$ [Animals]}

The mentioned metaphorical model relates to the sphere of interdisciplinary interaction because botanical picture of the world becomes a source of zoological knowledge of the scientific picture of the world in it, i.e., knowledge of different discursive fields is in the scientist's mind.

The problem of interdisciplinary scientific interaction inevitably leads to another important issue-the independence and autonomy of different scientific pictures of the world in the mind of a scientist, an expert. As this research shows, it is in the cognitive process of metaphorization that handling (comparing, comparison, division, structuring and generalization) knowledge of various discursive domains is taking place, which leads to the conclusion that various scientific pictures of the world are constantly interwoven notwithstanding all their relative autonomy and independence. They intersect in some of their fragments not only among themselves but also with the ordinary "naïve" worldview. In this way, there is an incorporation of new scientific concepts into 
the overall picture of the world, their development in the consciousness of the individual and the formation of a coherent picture of the world.

At the heart of the mechanism of the metaphorical model [plants $] \rightarrow$ [animals $]$ are dendrocentric views of the world. According to archaeological and historical records, the ancient person had imagined the whole universe in the form of the World Tree. Dendrocentric model belongs to the main pagan ideas of ancient people about the world order in addition to anthropocentric and zoocentric models. By virtue of its mythological and ancient nature, dendritic, or phytomorphic metaphor can be attributed to the scientific discourse archetypes.

\section{Metaphorical Sub Model [Tree] $\rightarrow$ [Animals]}

Concepts from the sphere of "tree" are used to describe the zoological objects:

- By the general appearance: In Russian: Morskiye zheludi [barnacles] (marine crustaceans with lime shell with a lid of the movable plates), stvol pera [feather rod] (upper part of the bird feather rod to which is a fan is attached), in the Kazakh language: теңүiз жанудавы (barnacles), қауырсын баванасы (feather rod)

- By the shape: In the Russian language: Zarodyshevye listki [embryonic leaves] (the germ layers, germ layers of the body of multicellular animals), in the Kazakh language: ұрық жапырақтары (embryonic leaves). The Kazakh term lacks diminutive semantics existing in the Russian term listki [leaves] with the affix -k-, which is associated with less common diminutive affixes to in the morphemic structure of the Kazakh nouns. The diminutive meaning is transferred mainly by lexical means. It is worth noting that the mentioned peculiarity can be addressed to all terminological nominations in the Kazakh zoodiscourse

- By the function and place: In Russian: Koren zuba [the tooth root] (a part of the tooth which is in the socket), koren volosa [the hair root] (a part of the hair immersed in the skin), kora mozga [cerebral cortex] (surface layer of gray matter disposed on the periphery of the cerebral hemispheres and covering them); in the Kazakh language: mic myбipi [the tooth root], шаштың mүбipi [the hair root], ми қабывы [cerebral cortex]

- The terms of Greco-Latin origin, functioning in the Russian scientific discourse, are also built on a similar mechanism: Blastula (Greek-sprout) (multicellular animal embryo), gemmules (winter resting bud inside many freshwater species) from the

Latin gemmula [little bud], pedicellariae (multiple appendages of the skeleton of sea urchins shaped as tweezers) from the Latin pediculus [stalk, stem].

\section{Metaphorical Sub Model [Other Plants] $\rightarrow$ [Animals]}

Other phytomorphic metaphors based on knowledge of other plants (not trees) characterize zoological objects and processes by the following parameters:

- The shape: In the Russian language: Lukovitsa volosa [the hair follicle] (the extension at the end of the hair root in the skin), lukovitsa aorty [the bulb of the aorta] (the extension of the abdominal aorta in bony fish), morskiye butony [marine buds] (one of completely extinct class of echinoderms)

- The general appearance: In the Russian language: Morskiye lilii [sea lilies] (one of the classes of echinoderms combining forms, the body of which consists of a stalk or antennae, cup and "hand" substituting it), morskiye ogurtsy [sea cucumbers] (class of marine invertebrates with a worm-like body from a few millimeters up to two meters); in the Kazakh language: теңіз лалагүлі (sea lilies), теңіз құияы (sea cucumber)

In similar Kazakh terms шаш түбінің буылтывы (similar to lukovitsa volosa [the hair follicle], literallythe hair root knot), аорта буылтывы (similar to lukovitsa aorty [the bulb of the aorta], literally-aortic knot) the initial conceptual field is grounded not on flora, as in Russian terms, but everyday-home things "knot"буылтық. The choice in favor of this source of knowledge has been determined by the special significance of the concept of a "knot" in the Kazakh cultural tradition. For the nomadic life, a rope and actions related to it were used in everyday life: necessary migrations things were knot with a rope, Kazakh dwelling-a yurt was built with the help of ropes, some of its parts were attached by knots; the term "knot" was ritual and sacred in nature in the spiritual culture of the nomads, for example, in the rite of "тусау кесер" (referring to a child, literally: "Cutting off manacles" so that a child is able to walk), etc.

We note also that metaphorical models, in which the source sphere is flora, are uncharacteristic of the Kazakh culture which is related mostly to cattle, but not to agriculture. Metaphor such as теңіз бітеугулі (similar morskiye butony [marine buds], literally-cleistogamous flower) is a semantic loan word of a Russian term.

The notion of the "seed" is actively in-demand in this model: In the Russian language: Semya (sperm), semennaya zhidkost (sperm), semyanosets (placenta in mammals), semyenniki [testes] (organ of male reproductive system in which the formation of male sex cells-sperm-takes place), semyavhod [micropyle] (the hole through which the sperm enters the female sexual organ), semyapriemnik [collection receptacle] (spermatheca); in the Kazakh language: ұрық (sperm), 
(ұрық) шәуеті (sperm, seminal fluid), ұрық жолдасы (placenta, lit. seed pal), жұмалақ оr аталық ұрық безі (male testes), ұрық енетін тесік (micropyle), ұрыққабылдауыш (spermatheca). Operating with this notion, researchers fully and in detail recreate the process of fertilization and reproduction in various animal species, by analogy with these processes in the plant world.

\section{Discussion}

In the course of the research, we came to the following inferences that are not contrary to our hypothesis and are confirmed by a detailed analysis of the linguistic material taken from terminological dictionaries in the Kazakh and the Russian languages: Kazakh-Russian, Russian-Kazakh terminological dictionary (Kusainova, 2000), Kazakh-Russian Dictionary (Syzdykova and Hussain, 2002); The Russian-English Dictionary of Biology (Dumbleton, 2000); Popular Dictionary of Biology (Babarykin, 2009). Number of the analyzed terminological units amounts to 465 , of which 241 in the Russian language, 224 in the Kazakh language.

First, much of the terminological metaphors in zoodiscourse are built on the universal archetypal models-anthropomorphic, zoomorphic and phytomorphic/dendromorphic. These models are widely used today for the nomination of new concepts in scientific discourse.

Second, metaphors generated within the universals are the same in languages under our investigationRussian and Kazakh. Many of them date back to the Greco-Latin designations of zoological concepts, as they are also based on the metaphorical universals.

Third, in science communication, metaphorical expression functions as a ready-made term conveying purely scientific information in accordance with the target attitude of participants of communication. Communicants do not realize its metaphorical nature, since the connection with the source area is "erased" with zoometaphors functioning for a long time. But this relationship does not disappear, going to a deeper ontological level, where the metaphorical model can go back into the general human knowledge base, already overgrown with new meanings, associations.

Fourth, comparative analysis of metaphorical terms in the Kazakh and the Russian zoological discourse indicates that a small part of the terms are different due to different structural features of the language (minimal diminutive affixes in the Kazakh language and, on the contrary, broad word-formation morphemic possibilities in the Russian language regarding it) and the differences in the selection of individual features in the mechanism of analogy, arising from the specific understanding of the world, geographical, climatic, economic and living conditions of the Russian and Kazakh peoples.

\section{Conclusion}

Thus, the analysis of scientific zoological terminology confirms the metaphoricity of the language of science, generated by the cognitive mechanism of analogy, which is due to the specifics of the scientific knowledge: The interaction of rational and irrational ways of knowing; combinability of unknown and familiar information; handling holistic cognitive structures. The scientific metaphor is formed on the basis of conceptual structures already formed in each of the ethnic culture that have been restated in the language structures. There are no rigid boundaries between scientific thinking and "secular" consciousness, therefore scientific knowledge uses general human knowledge about the world in the process of representing knowledge in any scientific field.

\section{Acknowledgement}

We express our gratitude to the rector of Pavlodar Pedagogical Institute, professor N.R. Arshabekov for his support of the research.

\section{Funding Information}

The research was carried out through a grant from Pavlodar Pedagogical Institute (the order dated 2, March, 2016).

\section{Author's Contributions}

Zifa Kakbaevna Temirgazina: Designed the research plan, organized the study, developed the methodology for analyzing the material involved in the collection and analysis of terms in the Russian and Kazakh languages, described the results of the study as well as coordinated the activities of the research team.

Uldanai Maksutovna Bakhtikireeva: Participated in the collection of terms in the Russian and Kazakh languages, in making their comparative analysis, as well as in the description of the research results.

Vladimir Pavlovich Sinyachkin: Participated in the analysis of terms in the Russian language, made a contribution to the description of the research results.

Marzhan Kasymovna Akosheva: Coordinated the mouse work, participated in the collection of terms in the Kazakh language, in their analysis, as well as in the description of the research results.

\section{Ethics}

This article is original and contains unpublished material. The corresponding author confirms that all of the other authors have read and approved the manuscript and no ethical issues involved. 


\section{References}

Babarykin, T.S., 2009. Popular biological dictionary. Phoenix. Rostov n/D.

Baranov, A.N., 2004. Metaphorical models as discursive practices. Literature Language, 63: 33-43.

Croft, W. and D.A. Cruse, 2004. Cognitive Linguistics. 1st Edn., Cambridge University Press, New York, ISBN-10: 0521667704, pp: 356.

Dumbleton, K.U., 2000. Russian-English Dictionary of Biology. Technical dictionaries, $\mathrm{M}$.

Dudetskaya, S.G., 2007. Metaphorization as a way of term formation. PhD Thesis, Samara.

Fauconnier, G. and M. Turner, 1998. Conceptual integration networks. Cognit. Sci., 22: 133-187. DOI: $10.1207 / \mathrm{s} 15516709 \operatorname{cog} 2202 \_1$

Galkina, O.V., 2004. Metaphor as a learning tool. PhD Thesis, Sciences, Tver.

Gusev, S.S., 1984. Science and Metaphor. 1st Edn., Publishing House of Leningrad University, Leningrad.

Johnson, M., 1987. The Body in the Mind: The Bodily Basis of Meaning, Imagination and Reason. 1st Edn., University of Chicago Press, Chicago, ISBN-10: 0226403173, pp: 272.

Kornilov, O.A., 1999. Linguistic picture of the world as derivatives of national mentalities. MSU Press, Moscow.

Kuliev, G.G., 1987. Metaphor and scientific knowledge. Elm, Baku.

Kusainova, A.K., 2000. Kazakh-Russian, RussianKazakh terminological dictionary. Rauan. Almaty.

Lakoff, G., 1990. The Invariance Hypothesis: Is abstract reason based on image-schemas? Cognitive Linguist., 1: 54-71. DOI: 10.1515/cogl.1990.1.1.39

Lakoff, G., 1998. Cognitive Semantics. In: Meaning and Mental Representations, Eco, V. (Ed.), Indiana University Press, Bloomington, ISBN-10: 0253337240, pp: 119-154.

Lakoff, G., 2004. Metaphors We Live by. Translated from English, Baranov, A.N. (Eds.), URSS, Moscow.

Losev, A.F., 1977. Ancient History of Philosophy. M., Science, pp: 31.

Makhnitskaya, E.Y., 2003. The metaphor of the modern economic discourse and the principles of lexicographic description. Rostov-on-Don.
Mishankina, N.A., 2010. Linguistic and cognitive modeling of scientific discourse. PhD Thesis, Tomsk.

Ovsyannikov, V.V., 2009. "Tissue" metaphor in natural science texts. Proceedings of the Collection of Articles of International Scientific-Practical Conference, (SPC' 09), Tomsk, pp: 102-109.

Rezanova, Z.I., 2007a. The metaphor in the linguistic text: types of functioning. Bull. Tomsk State University, 1: 18-29.

Rezanova, Z.I., 2007b. The spatial metaphor in the linguistic text. In: Views of the Russian world: Spatial patterns in the language and text, UFO-Plus, Tomsk, pp: 326-357.

Sedov, A.E., 2000. Metaphors in genetics. Bull. Russian Acad. Sci., 70: 526-534.

Serbinovskaya, N.V., 2009. "Marketing" terminology field in the Russian language. SRSTU, Novocherkassk.

Shimizu, H., H. Saito and M. Hoshiyama, 2006a. Characteristics of processing for trait adjectives in depressive persons: An event-related potential study. Nagoya J. Med. Sci., 68: 27-33. PMID: 16579173.

Shimizu, H., H. Saito and M. Hoshiyama, 2006b. Cognitive mechanism for meaning of emotive words in depressed personality: An event-related potential study. Nagoya J. Med. Sci., 68: 35-44. PMID: 16579174.

Stepanov, Y.S., 1995. The changing "image of the language" in the science of the 20th century. In: Language and Science at the end of the 20th century, Moscow, pp: 7-34.

Stepanov, Y.S., 1998. The language and method: To the contemporary philosophy of the language. Yazyki Russkoy kultury, Moscow.

Syzdykova, R.G., Husain K.S., 2002. Kazakh-Russian Dictionary. Dyke-Press, Almaty.

Temirgazina, Z.K., K.A. Orazalinova and G.A. Khamitova, 2016. Didactic Features of the Learner's English-Russian Dictionary of Biology Development. Res. J. Pharmaceut. Biol. Chem. Sci., 7: 317-326. 